\section{Faktor-Faktor Yang Berpengaruh Terhadap Keputusan Pembelian Konsumen Toko Ramona Palembang}

\author{
Zulkifli Djamin \\ Sekolah Tinggi Ilmu Ekonomi APRIN \\ Email: zulkifli.djamin@gmail.com
}

Submitted: SEPTEMBER 2020

Accepted:

\begin{abstract}
ABSTRAK
Dewasa ini Retail atau Minimarket semakin banyak dibuka di berbagai tempat baik di kota besar maupun di kota kecil, termasuk di kota Palembang. Kehadiran pasar swalayan dan minimarket merupakan tuntutan perubahan gaya hidup masyarakat kota. Persaingan yang semakin ketat di mana semakin banyak produsen yang terlibat dalam pemenuhan kebutuhan dan keinginan konsumen, menyebabkan setiap perusahaan harus menempatkan orientasi pada kepuasan konsumen sebagai tujuan utama. Tujuan penelitian adalah (1) Untuk mengetahui adanya pengaruh dari faktor produk, pelayanan, dan lokasi terhadap keputusan pembelian konsumen pada Toko Ramona Palembang, (2) Untuk mengetahui seberapa besar pengaruh dari faktor produk, pelayanan, dan lokasi terhadap keputusan pembelian konsumen pada Toko Ramona Palembang. (3) Untuk mengetahui faktor manakah diantara faktor produk, pelayanan, dan lokasi yang memberikan pengaruh terbesar terhadap keputusan pembelian konsumen pada Toko Ramona Palembang.
\end{abstract}

Kata Kunci: Keputusan Pembelian, Konsumen, Ritel

\section{PENDAHULUAN}

Kemajuan di bidang perekonomian selama ini telah banyak membawa akibat perkembangan yang cukup pesat dalam bidang usaha. Sejalan dengan itu banyak bermunculan perusahaan dagang yang bergerak di bidang perdagangan eceran yang berbentuk toko, minimarket, pasar swalayan dan lain-lain. Hal ini menimbulkan persaingan di antara perusahaan-perusahaan tersebut. Agar suatu perusahaan dapat terus dan memenangkan persaingan, perusahaan dituntut untuk mengadakan perbaikan dan peningkatan di bidang pemasaran.

Perbaikan dan peningkatan kegiatan di bidang pemasaran harus dilaksanakan secara terencana. Atau dengan kata lain, perusahaan harus menentukan strategi pemasaran yang tepat. Perubahan lingkungan perusahaan terutama faktor pesaing yang mampu menghasilkan produk yang sama, menyebabkan banyak perusahaan berorientasi pada konsumen (customer oriented). Perusahaan yang berorientasi pada konsumen hendaknya selalu memikirkan apa yang dibutuhkan oleh konsumen, apa yang diinginkan konsumen, dan pelayanan yang bagaimana disenangi oleh konsumen sehingga konsumen tidak hanya puas, akan tetapi menjadi loyal dan kembali pada tokonya.

Dewasa ini Retail atau Minimarket semakin banyak dibuka di berbagai tempat baik di kota besar maupun di kota kecil, termasuk di kota Palembang. Kehadiran pasar swalayan dan minimarket merupakan tuntutan perubahan gaya hidup masyarakat kota. Kondisi semacam ini mencerminkan suatu fenomena yang terjadi bahwa masyarakat menjadi semakin kritis dalam memilih tempat pembelanjaan. Sifat kritis tersebut dicirikan antara

\section{JIMKES}

Jurnal Ilmiah Manajemen Kesatuan
Vol. 8 No. 3, 2020 pp. $317-328$ IBI Kesatuan
ISSN $2337-7860$ E-ISSN $2721-169 \mathrm{X}$ 
Consumer

Purchasing

Decision and Retail

lain masyarakat menginginkan barang selengkap mungkin, produk yang berkualitas, pelayanan dan fasilitas yang memuaskan yang semuanya terdapat dalam satu toko yaitu pasar swalayan atau minimarket.

Persaingan yang semakin ketat di mana semakin banyak produsen yang terlibat dalam pemenuhan kebutuhan dan keinginan konsumen, menyebabkan setiap perusahaan harus menempatkan orientasi pada kepuasan konsumen sebagai tujuan utama (Fandy Tjiptono,2010:24). Dengan semakin banyaknya produsen yang menawarkan produk dan jasa, maka konsumen memiliki pilihan yang semakin banyak untuk menentukan jadi tidaknya pembelian.

Pasar swalayan menyediakan berbagai kebutuhan konsumen dalam jumlah yang cukup besar dengan keuntungan yang kecil pada tiap unitnya seperti didefinisikan Philip Kotler (2010:593) bahwa pasar swalayan merupakan suatu bentuk usaha eceran yang mempunyai operasi relatif besar, margin yang rendah, volume yang tinggi, dan bersifat swalayan yang dirancang untuk memenuhi kebutuhan konsumen. Dengan keuntungan yang kecil itu maka diharapkan swalayan mampu mencapai volume jual yang tinggi agar keuntungan yang diperoleh dapat maksimal.

Dalam perjalanannya pasar swalayan semakin meningkat baik dalam jumlah maupun pelayanan yang diberikan. Keadaan tersebut menyebabkan adanya persaingan pada bisnis retail. Akibatnya mau tidak mau para pengusaha bisnis retail (pemilik pasar swalayan) tidak mempunyai pilihan lain kecuali memenangkan persaingan. Berkaitan dengan konsep pemasaran yang berorientasi pada konsumen maka manajemen pasar swalayan dapat memberikan kepuasan konsumen dengan cara memenuhi kebutuhan dan keinginannya.

Dari survei pendahuluan yang dilakukan diketahui bahwa akhir-akhir ini jumlah pengunjung yang datang untuk membeli di Toko Ramona Palembang cenderung mengalami penurunan seperti tampak pada Gambar 1 .

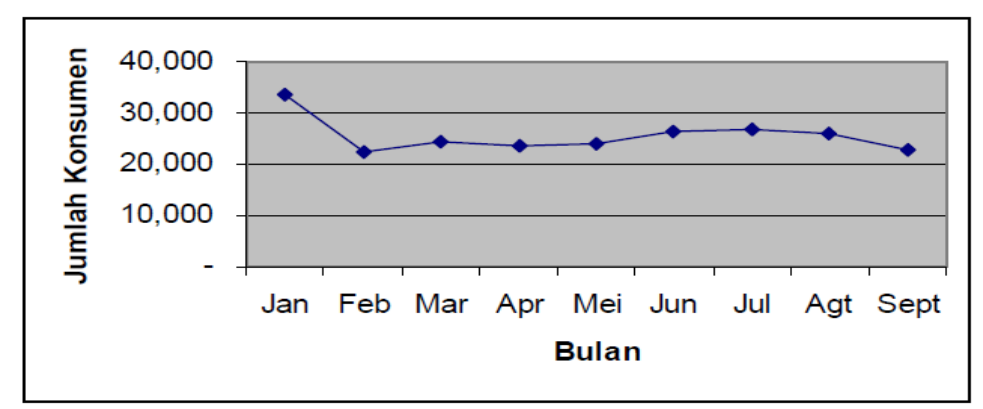

(Sumber: Toko Ramona Palembang, 2019)

\section{Gambar 1 Data Pengunjung Toko Mega Palembang}

Gambar di atas menunjukkan bahwa pengunjung Toko Ramona yang berada di kota Palembang pada akhir-akhir ini sedang menghadapi masalah yaitu adanya jumlah pengunjung swalayan tidak menunjukkan peningkatan secara jelas bahkan cenderung menurun. Toko Ramona Palembang bukan satu-satunya toko retail yang ada di Palembang. Untuk menghadapi persaingan, maka mau tidak mau pemilik swalayan tidak mempunyai pilihan lain kecuali memenangkan persaingan dengan cara merebut konsumen sebanyak mungkin. Fakta di atas dapat dimaknai sebagai adanya masalah pasar swalayan dalam strategi pemasaran.

Strategi pemasaran terdiri dari unsur-unsur pemasaran yang terpadu (4 $\mathrm{P}$ dari marketing mix, yaitu product, price, promotion, place) yang selalu berkembang sejalan dengan gerak perusahaan dan perubahan-perubahan lingkungan pemasarannya serta perubahan perilaku konsumen (Basu Swasta dan T Hani Handoko,2010:119). Perilaku konsumen yang dimaksudkan di sini tentu saja perilaku konsumen yang nantinya akan mendatangkan pendapatan bagi swalayan tersebut. Menurut Sofjan Assauri (2014:170) strategi pemasaran merupakan rencana yang menyeluruh, terpadu dan menyatu di bidang pemasaran, yang memberikan panduan tentang kegiatan yang akan dijalankan untuk 
dapat tercapainya tujuan pemasaran suatu perusahaan yang meliputi produk, harga, lokasi, promosi, dan pelayanan

Apabila strategi bauran pemasaran ini sukses, maka pengaruhnya terhadap perilaku

pembelian konsumen akan berakhir pada pengambilan keputusan pembelian. Keputusan pembelian merupakan perilaku pembelian seseorang dalam menentukan suatu pilihan produk untuk mencapai kepuasan sesuai dengan kebutuhan dan keinginan konsumen. Di mana pengambilan keputusan membeli ini melewati tahap-tahap mulai dari pengenalan masalah, pencarian informasi, evaluasi alternatif, keputusan pembelian, sampai perilaku pasca pembelian. (Basu Swasta dan T Hani Handoko,2010:106).

Pada penelitian ini, dipilih Toko Ramona Palembang yang berlokasi di Jalan Inspektur Marzuki No.89 Pakjo Palembang sebagai obyek penelitian. Sedangkan faktor-faktor yang akan diteliti adalah menekankan pada faktor produk, pelayanan, dan lokasi terhadap keputusan pembelian konsumen.

Produk adalah suatu sifat yang komplek baik dapat diraba maupun tidak dapat diraba termasuk bungkus, warna, dan harga yang dapat diterima oleh pembeli untuk memuaskan kebutuhan dan keinginannya (Basu Swasta,1996:94). Jadi, untuk faktor harga sengaja tidak diteliti karena peneliti memiliki asumsi bahwa faktor harga sudah dapat terwakili melalui faktor produk sedangkan untuk faktor promosi Toko Ramona Palembang tidak melakukan promosi terhadap produknya karena promosi dari tiap-tiap produk yang dijual di toko merupakan tanggung jawab produsen untuk melakukan promosi bagi produknya masing-masing.

Oleh karena itu, untuk dapat menarik konsumen dan dapat bersaing dengan swalayan/retail lain, maka hal yang dilakukan swalayan adalah memenuhi kebutuhan dan keinginan konsumen sehingga konsumen mencapai kepuasan dengan cara memberikan produk yang berkualitas dan selengkap mungkin, pelayanan yang memuaskan, dan lokasi yang memadai sehingga akan mempengaruhi keputusan pembelian konsumen.

Sesuai keterkaitan antara produk, pelayanan, dan lokasi dengan keputusan pembelian konsumen yang telah diuraikan dalam latar belakang di atas, maka permasalahan yang akan dikaji dalam penelitian ini adalah:

a. Adakah pengaruh produk, pelayanan, dan lokasi terhadap keputusan pembelian konsumen pada Toko Ramona Palembang?

b. Seberapa besar pengaruh produk, pelayanan, dan lokasi terhadap keputusan pembelian konsumen pada Toko Ramona Palembang?

c. Faktor manakah dari produk, pelayanan, dan lokasi yang memberikan pengaruh terbesar terhadap keputusan pembelian konsumen pada Toko Ramona Palembang?

Pasar swalayan atau Retail merupakan suatu bentuk usaha eceran yang mempunyai operasi relatif besar, margin yang rendah, volume yang tinggi, dan bersifat swalayan yang dirancang untuk memenuhi kebutuhan dan keinginannya (Philip Kotler,2010:593). Setiap perusahaan dalam hal ini pasar swalayan mempunyai tujuan untuk dapat tetap hidup dan berkembang. Tujuan tersebut hanya dapat dicapai melalui usaha mempertahankan dan meningkatkan keuntungan atau laba perusahaan. Usaha ini hanya dapat dilakukan apabila perusahaan dapat mempertahankan dan meningkatkan penjualannya melalui usaha mencari dan membina langganan serta usaha menguasai pasar.

Tujuan ini hanya dapat dicapai apabila bagian pemasaran melakukan strategi pemasaran yang tepat untuk dapat menggunakan kesempatan atau peluang yang ada dalam pemasaran, sehingga posisi perusahaan di pasar dapat dipertahankan dan sekaligus ditingkatkan. Keputusan pembelian konsumen terhadap suatu produk pada dasarnya erat kaitannya dengan perilaku konsumen. Perilaku konsumen merupakan unsur penting dalam kegiatan pemasaran suatu produk yang perlu diketahui oleh perusahaan.

Adanya kecenderungan pengaruh produk, pelayanan dan lokasi terhadap keputusan pembelian konsumen mengisyaratkan bahwa manajemen perusahaan perlu mempertimbangkan aspek perilaku konsumen terutama proses pengambilan keputusan 
Consumer

Purchasing

Decision and Retail pembelian. Keputusan membeli barang dapat dilakukan oleh konsumen apabila produk yang tersedia mempunyai kualitas yang baik, lengkap, harganya terjangkau, dan adanya jaminan yang memuaskan. Sehingga akan membuat konsumen lebih senang karena barang yang diinginkannya tidak mengecewakan.

Selain itu, konsumen lebih leluasa dalam memilih barang yang sesuai dengan kebutuhannya berdasarkannya jenis dan jumlahnya. Pelayanan yang baik dari pasar swalayan juga memegang peranan penting dalam melakukan keputusan pembelian konsumen. Dengan pelayanan yang baik, konsumen akan merasa diperhatikan dan dilayani sesuai dengan keinginannya. Pelayanan tersebut meliputi unsur kecepatan, ketepatan, keamanan, keramahtamahan, dan kenyamanan. Selain mempertimbangkan faktor produk, pelayanan, lokasi juga mempengaruhi keputusan pembelian.

Keputusan membeli dapat dilakukan oleh konsumen apabila tempat yang dituju lokasi yang mudah dijangkau, tersedianya fasilitas umum, letaknya strategis. Dengan alasan tersebut konsumen membutuhkan waktu yang sedikit untuk sampai tempat itu dan dapat menunjang kebutuhan yang lain. Konsumen akan membeli barang jika produk yang tersedia lengkap dan tidak mengecewakan, pelayanan yang menyenangkan, dan tempat yang dituju nyaman dan tidak membutuhkan waktu terlalu lama dalam memperolehnya sehingga konsumen akan melakukan pembelian ulang.

Dari uraian tersebut dapat disimpulkan bahwa dengan adanya faktor produk, pelayanan, dan lokasi dapat dijadikan sebagai bahan pertimbangan konsumen untuk mengambil keputusan membeli barang yang diinginkan. Secara sistematis hubungan antara variabel bebas dan variabel terikat dapat dibuat kerangka berpikir sebagai berikut:

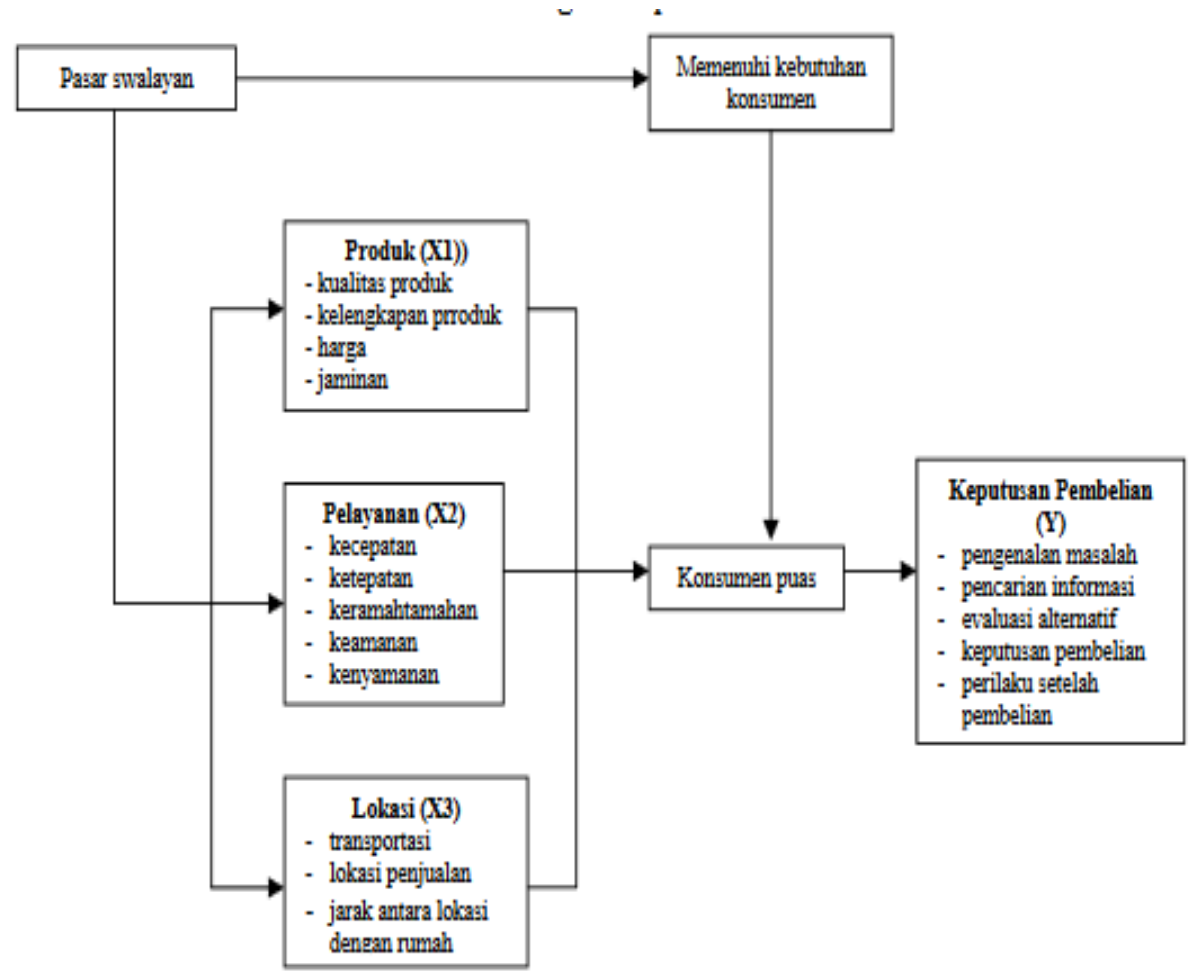

\section{Gambar 2. Kerangka berpikir}

\section{METODE PENELITIAN}

Dilihat dari segi bentuk dalam penelitian ada dua jenis data, yaitu data kualitatif dan data kuantitatif. Dan data yang digunakan dalam penelitian ini adalah dat kuantitatif. Data kuantitatif adalah data yang penekanannya pada data numerical (angka) yang diolah dengan metode statistika. Sumber data dalam penelitian adalah subjek dari mana data diperoleh. Apabila peneliti menggunakan kuesioner atau wawancara dalam 
pengumpulan datanya, maka sumber data tersebut responden. Apabila peneliti menggunakan observasi, maka sumber datanya bisa berupa benda, gerak atau proses sesuatu. Apabila peneliti menggunakan dokumentasi, maka dokumen atau catatan subjek penelitian atau variabel penelitian. Dalam penelitian ada dua jenis data, yaitu data primer dan data sekunder. Sumber data primer yaitu data yang diperoleh langsung dari sumber pertama. Sumber data yang penulis gunakan dalam penelitian ini adalah data yang diperoleh dengan cara wawancara secara langsung dengan karyawan, atau manajer Toko Mega yang terkait, serta penulis melakukan transaksi secar langsung guna memperoleh data yang akurat. Sumber data sekunder adalah sumber yang dapat memberikan informasi atau data tambahan yang dapat memperkuat data pokok, baik yang berupa manusia atau benda (majalah, buku, Koran, dll).

Berbagai data yang dikumpulkan dalam penelitian ini dilakukan dengan berbagai metode, yaitu: 1. Metode Interview (wawancara), 2. Metode Kuesioner (angket) dan 3. Metode Studi Pustaka. Kualitas data penelitian diukur dengan uji validitas, uji reliabilitas dan uji asumsi klasik. Kemudian dilakukan uji regresi dan korelasi

\section{HASIL DAN PEMBAHASAN \\ Hasil Penelitian}

Sesuai dengan tujuan analisis deskriptif yaitu untuk memberikan gambaran mengenai hasil penelitian secara umum, bagaimana karakteristik subyek penelitian sehubungan dengan variabel-variabel yang diteliti. Sebelum dilakukan analisis statistik terlebih dahulu dilakukan pembobotan terhadap skor masing-masing variabel. Pembobotan ini dilakukan dengan memberikan skor total dengan jumlah item dari variabel yang dibobot.

Hasil tanggapan dari 105 responden terhadap item-item kuesioner yang terbagi menjadi 5 item variabel produk, 6 item variabel pelayanan, 4 item variabel lokasi, dan 5 item variabel keputusan pembelian. Hasil analisis deskriptif persentase variabel-variabel penelitian setelah dilakukan pembobotan, terangkum dam tabel berikut ini:

1.Variabel Produk (X1)

Skor maksimal $=105 \times 5 \times 5=2625$. Skor minimal $=105 \times 5 \times 1=525$. Range $=$ Skor maksimal - Skor minimal $=2625-525=2100$. Panjang kelas interval $=52100=420$

Tabel 1. Hasil perhitungan Deskriptif Persentase variabel Produk

\begin{tabular}{|c|c|l|}
\hline Interval & \multicolumn{1}{|c|}{ Persentase } & \multicolumn{1}{|c|}{ Kategori } \\
\hline $2205<$ skor $\leq 2625$ & $84 \%<\% \leq 100 \%$ & Sangat Tinggi \\
$1785<$ skor $\leq 2205$ & $68 \%<\% \leq 84 \%$ & Tinggi \\
$1365<$ skor $\leq 1785$ & $52 \%<\% \leq 68 \%$ & Sedang \\
$945<$ skor $\leq 1365$ & $36 \%<\% \leq 52 \%$ & Rendah \\
$525 \leq$ skor $\leq 945$ & $20 \% \leq \% \leq 36 \%$ & Sangat Rendah \\
\hline
\end{tabular}

Untuk mengetahui berapa persentase produk digunakan rumus:

$\mathrm{DP}=$ Skor total/Skor Maksimal x $100 \%=1892 / 2625 \times 100 \%=72,1 \%$

Jika dihitung dengan skor $0,721 \times 2625=1892$. dari hasil perhitungan tersebut dapat disimpulkan bahwa produk yang ditawarkan di Toko Ramona Palembang termasuk kategori tinggi.

2.Variabel Pelayanan ( X2)

Skor maksimal $=105 \times 6 \times 5=3150$. Skor minimal $=105 \times 6 \times 1=630$. Range $=$ Skor maksimal - Skor minimal $=3150-630=2520$. Panjang kelas interval $=2520 / 4=504$

Untuk mengetahui berapa persentase pelayanan digunakan rumus:

DP $=$ Skor total/ Skor Maksimal x $100 \%$

$=1159 / 3150 \times 100 \%$

$=36,8 \%$
Consmer

Purchasing

Decision and Retail

321 
Consumer

Purchasing

Decision and Retail termasuk kategori rendah.
Jika dihitung dengan skor $0,368 \times 3150=1159$. Dari hasil perhitungan tersebut dapat disimpulkan bahwa pelayanan yang diberikan di Toko Ramona Palembang

Tabel 2. Hasil perhitungan Deskriptif Persentase variabel Pelayanan

\begin{tabular}{|c|c|l|}
\hline Interval & Persentase & \multicolumn{1}{|c|}{ Kategori } \\
\hline $2646<$ skor $\leq 3150$ & $84 \%<\% \leq 100 \%$ & Sangat Tinggi \\
$2142<$ skor $\leq 2646$ & $68 \%<\% \leq 84 \%$ & Tinggi \\
$1638<$ skor $\leq 2142$ & $52 \%<\% \leq 68 \%$ & Sedang \\
$1134<$ skor $\leq 1638$ & $36 \%<\% \leq 52 \%$ & Rendah \\
$630 \leq$ skor $\leq 1134$ & $20 \% \leq \% \leq 36 \%$ & Sangat Rendah \\
\hline
\end{tabular}

3.Variabel Lokasi ( X3)

Skor maksimal $=105 \times 4 \times 5=2100$. Skor minimal $=105 \times 4 \times 1=420$.Range $=$ Skor maksimal - Skor minimal $=2100-420=1680$. Panjang kelas interval $=1680 / 5=336$

Tabel 3 Hasil perhitungan Deskriptif Persentase variabel Lokasi

\begin{tabular}{|c|c|l|}
\hline Interval & Persentase & \multicolumn{1}{|c|}{ Kategori } \\
\hline $1764<$ skor $\leq 2100$ & $84 \%<\% \leq 100 \%$ & Sangat Tinggi \\
$1428<$ skor $\leq 1764$ & $68 \%<\% \leq 84 \%$ & Tinggi \\
$1092<$ skor $\leq 1428$ & $52 \%<\% \leq 68 \%$ & Sedang \\
$756<$ skor $\leq 1092$ & $36 \%<\% \leq 52 \%$ & Rendah \\
$420 \leq$ skor $\leq 756$ & $20 \% \leq \% \leq 36 \%$ & Sangat Rendah \\
\hline
\end{tabular}

Untuk mengetahui berapa persentase lokasi digunakan rumus:

DP $=$ Skor total $/$ Skor Maksimal x $100 \%$

$=1236 / 2100 \times 100 \%=58,9 \%$

Jika dihitung dengan skor $0,589 \times 2100=1236$. Dari hasil perhitungan tersebut dapat disimpulkan bahwa lokasi di Toko Ramona Palembang termasuk kategori sedang.

4.Variabel Keputusan pembelian $(\mathrm{Y})$

Skor maksimal $=105 \times 5 \times 5=2625$. Skor minimal $=105 \times 5 \times 1=525$. Range $=$ Skor maksimal - Skor minimal $=2625-525=2100$. Panjang kelas interval $=2100 / 5=420$

Tabel 4. Hasil Perhitungan Deskriptif Persentase Variabel Keputusan Pembelian

\begin{tabular}{|c|c|l|}
\hline Interval & Persentase & Kategori \\
\hline $2205<$ skor $\leq 2625$ & $84 \%<\% \leq 100 \%$ & Sangat Tinggi \\
$1785<$ skor $\leq 2205$ & $68 \%<\% \leq 84 \%$ & Tinggi \\
$1365<$ skor $\leq 1785$ & $52 \%<\% \leq 68 \%$ & Sedang \\
$945<$ skor $\leq 1365$ & $36 \%<\% \leq 52 \%$ & Rendah \\
$525 \leq$ skor $\leq 945$ & $20 \% \leq \% \leq 36 \%$ & Sangat Rendah \\
\hline
\end{tabular}

Untuk mengetahui berapa persentase keputusan pembelian digunakan rumus:

$\mathrm{DP}=$ Skor Total/Skor Maksimal x $100 \%$

$$
=26251850 \times 100 \%=70,5 \%
$$


Jika dihitung dengan skor 0,705 × $2625=1850$. Dari hasil perhitungan tersebut dapat disimpulkan bahwa keputusan pembelian di Toko Ramona Palembang termasuk kategori tinggi.

\section{Analisis Regresi Produk, Pelayanan, dan Lokasi tarhadap Keputusan Pembelian}

Dalam melakukan analisis terhadap hubungan dan pengaruh produk, pelayanan, dan lokasi terhadap keputusan konsumen dalam membeli produk di pasar swalayan Indo Rizky Purbalingga digunakan analisis regresi berganda. Bentuk model yang digunakan adalah sebagai berikut:

$$
\mathrm{Y}=\mathrm{a}+\mathrm{b} 1 \mathrm{X} 1+\mathrm{b} 2 \mathrm{X} 2+\mathrm{b} 3 \mathrm{X} 3
$$

Keterangan:

$\mathrm{Y}=$ Keputusan konsumen dalam membeli produk

$\mathrm{X} 1=$ Produk

$\mathrm{X} 2=$ Pelayanan

$\mathrm{X} 3=$ Lokasi

$\mathrm{a}=$ Konstanta

$\mathrm{b} 1, \mathrm{~b} 2, \mathrm{~b} 3$ = koefisien regresi masing-masing variabel

Hasil dari analisis regresi dilakukan untuk mengetahui ada tidaknya pengaruh antara produk, pelayanan, dan lokasi terhadap keputusan pembelian dapat dilihat pada tabel 5 berikut ini:

Tabel 5. Hasil Analisis Regresi

\begin{tabular}{|l|l|}
\hline \multicolumn{1}{|c|}{ Keterangan } & Hasil Analisis \\
\hline Konstanta & 4,66 \\
koefisien regresi produk $\left(\mathrm{b}_{1}\right)$ & 0,204 \\
koefisien pelayanan $\left(\mathrm{b}_{2}\right)$ & 0,4655 \\
koefisien lokasi $\left(\mathrm{b}_{3}\right)$ & 0,352 \\
$\mathrm{~F}_{\text {hitung }}$ & 79,053 \\
$\mathrm{t}_{\text {hit }}$ produk & 2,911 \\
$\mathrm{t}_{\text {hit }}$ pelayanan & 6,231 \\
$\mathrm{t}_{\text {hit }}$ lokasi & 5,864 \\
koefisien determinasi $(\mathrm{R})$ square & 0,701 \\
Adjusted $\mathrm{R}^{2}$ & 0,692 \\
koefisien regresi simultan $(\mathrm{R})$ & 0,837 \\
\hline
\end{tabular}

Dari tabel tersebut dapat disusun persamaan regresi sebagai berikut:

$$
\mathrm{Y}=4,66+0,204 \mathrm{X} 1+0,4655 \mathrm{X} 2+0,352 \mathrm{X} 3
$$

Koefisien regresi tersebut bertanda positif $(+)$, artinya kenaikan variabel independent akan diikuti oleh kenaikan variabel dependent. Dari persamaan regresi di atas dapat diartikan sebagai berikut:

- $\quad$ konstanta (a) $=4,66$, artinya bahwa jika tidak ada produk, pelayanan, dan lokasi maka keputusan konsumen dalam melakukan pembelian adalah sebesar 4,66.

- $\quad$ Koefisien regresi $(\mathrm{b} 1)=0,204$, artinya jika produk yang diberikan pramuniaga Toko Mega Palembang skornya naik 1 satuan sementara faktor pelayanan dan lokasi tetap maka keputusan konsumen dalam membeli produk (Y) akan mengalami kenaikan sebesar 0,204.

- $\quad$ Koefisien regresi $(\mathrm{b} 2)=0,4655$, artinya jika pelayanan yang diberikan pramuniaga Toko Mega Palembang skornya naik 1 satuan sementara faktor produk dan lokasi tetap maka keputusan konsumen dalam membeli produk (Y) akan mengalami kenaikan sebesar 0,4655 .

- $\quad$ Koefisien regresi $(\mathrm{b} 3)=0,352$, artinya jika lokasi yang diberikan Toko Mega Palembang skornya naik 1 satuan sementara faktor produk dan pelayanan tetap maka keputusan konsumen dalam membeli produk (Y) akan mengalami kenaikan sebesar 0,352 .

Uji $\mathrm{F}$ atau Simultan dilakukan untuk mengetahui pengaruh semua variabel independen yang terdapat di dalam model secara bersama-sama (simultan) terhadap 
Consumer

Purchasing

Decision and Retail variabel dependen. Berdasarkan hasil perhitungan regresi linier berganda dengan program SPSS seperti pada lampiran diperoleh persaman regresi sebagai berikut:

$$
\mathrm{Y}=4,66+0,204 \mathrm{X} 1+0,4655 \mathrm{X} 2+0,352 \mathrm{X} 3
$$

Untuk membuktikan kebenaran hipotesis digunakan uji $\mathrm{F}$ yaitu untuk mengetahui sejauh mana variabel produk, pelayanan, dan lokasi mampu menjelaskan atau berpengaruh terhadap variabel keputusan pembelian konsumen. Cara yang digunakan adalah dengan membandingkan nilai Ftabel dengan Fhitung, apabila nilai Fhitung > Ftabel maka Ho ditolak, sehingga dapat dikatakan bahwa variabel bebas dari model regresi dapat menerangkan variabel terikat secara serentak. Sebaliknya, jika Fhitung < Ftabel maka Ho diterima, dengan demikian dapat dikatakan bahwa variabel bebas dari model regresi linier berganda tidak mampu menjelaskan variabel terikatnya.

Berdasarkan hasil analisis regresi SPSS pada lampiran diketahui $\mathrm{F}$ hitung sebesar 79,053 dan Ftabel $=3,0864$ dari hasil perhitungan tersebut tampak bahwa Fhitung $>\mathrm{F}$ tabel, yaitu 79,053 > 3,0864. Dengan demikian Ho ditolak dan Ha diterima. Artinya secara simultan produk, pelayanan, dan lokasi berpengaruh signifikan terhadap keputusan konsumen dalam membeli produk. Sehingga hipotesis yang berbunyi produk, pelayanan, dan lokasi secara simultan berpengaruh signifikan terhadap keputusan konsumen dalam membeli produk di Toko Ramona Palembang diterima. Dalam analisis regresi linier berganda ini dianalisis pula besarnya koefisien determinasi (R2) secara keseluruhan.

Jika R2 yang diperoleh mendekati 1 (satu) maka dapat dikatakan semakin kuat model tersebut dalam menerangkan variasi variabel bebas terhadap variabel terikat. Sebaliknya, jika R2 mendekati 0 (nol) maka semakin lemah model tersebut dalam menerangkan variasi variabel bebas terhadap variabel terikat. Berdasarkan hasil perhitungan koefisien determinasi (R2) diperoleh hasil sebesar 0,701. Hal ini berarti bahwa persentase pengaruh produk, pelayanan, dan lokasi terhadap keputusan pembelian konsumen sebesar 70,1\%. Sedangkan sisanya sebesar 29,9\% dipengaruhi oleh faktor lain yang tidak diteliti.

Uji t yang digunakan adalah secara individu (parsial) yaitu suatu pengujian terhadap pengaruh masing-masing variabel independen terhadap variabel dependen. Hasil pengujian koefisien regresi produk, pelayanan, dan lokasi terhadap keputusan konsumen dalam membeli produk adalah sebagai berikut:

- Nilai thitung untuk koefisien regresi dapat diketahui dari hasil perhitungan komputer. Besarnya masing-masing nilai thitung dari masing-masing regresi dapat dilihat pada Tabel 4.5 .

- Nilai kritis atau ttabel pada taraf signifikansi $5 \%$ adalah 1,983 . sedangkan thitung produk thitung $\mathrm{X} 1=2,911$ dan thitung pelayanan thitung $\mathrm{X} 2=6,231$ dan thitung lokasi thitung X3 $=5,864$. Dan hasil tersebut dapat diambil kesimpulan bahwa nilai thitung koefisien regresi dari produk, pelayanan, dan lokasi lebih besar dari ttabel, sehingga produk, pelayanan, dan lokasi mempunyai hubungan yang signifikan terhadap keputusan pembelian.

Selain melakukan pembuktian dengan uji $\mathrm{F}$, uji R2, dan uji t, maka perlu juga mencari besarnya koefisien determinasi (r2) parsialnya untuk masing-masing variabel bebas. Berdasarkan hasil perhitungan ternyata faktor yang mempunyai pengaruh paling besar terhadap pembelian konsumen adalah faktor pelayanan yaitu sebesar 0,2777 (27,77 \%) yang diperolehnya dari koefisien korelasi parsial untuk strategi pelayanan dikuadratkan. Koefisien determinasi parsial untuk lokasi sebesar 0,2540 (25,40\%) yang diperolehnya dari koefisien korelasi parsial untuk strategi lokasi dikuadratkan. Sedangkan koefisien determinasi (r2) parsialnya untuk variabel strategi produk sebesar 0,0773 (7,73\%) yang diperoleh dari koefisien parsial untuk variabel strategi produk yang dikuadratkan.

Hal ini berarti bahwa sumbangan parsial dari variabel produk terhadap keputusan pembelian konsumen sebesar 7,73 \%, sumbangan parsial dari variabel pelayanan terhadap keputusan pembelian konsumen sebesar $27,77 \%$, dan sumbangan parsial dari variabel lokasi terhadap keputusan pembelian konsumen sebesar 25,40 \%. 
1. Uji Multikolinieritas. Penyimpangan asumsi klasik yang pertama adalah adanya multikolieritas dalam model regresi yang dihasilkan. Hal ini digunakan untuk mengetahui apakah model regresi yang dihasilkan baik untuk menaksir nilai variabel independen. Menurut Cooper dan Emory (2009:154) apabila rhitung kurang dari 0,8 maka gejala multikolinieritas dapat diabaikan. Berdasarkan hasil perhitungan komputer program SPSS diperoleh hasil rhitung seperti pada tabel 6 berikut ini:

Tabel 6 Korelasi antara Produk, Pelayanan, dan Lokasi

\begin{tabular}{|c|c|c|c|c|}
\hline & Y & X1 & X2 & X3 \\
\hline Korelasi Y & 1,000 & 0,451 & 0,744 & 0,733 \\
X1 & 0,451 & 1,000 & 0,330 & 0,330 \\
X2 & 0,744 & 0,333 & 1,000 & 0,613 \\
X3 & 0,733 & 0,333 & 0,613 & 1,000 \\
\hline
\end{tabular}

Dari Tabel 6 dapat dilihat bahwa besarnya koefisien korelasi antara faktor produk (X1), pelayanan (X2), dan lokasi (X3) kurang dari 0,8. ini berarti bahwa dalam regresi yang dihasilkan tidak terjadi multikolinieritas

2. Uji Heteroskedastisitas

Penyimpangan asumsi klasik yang kedua adalah heteroskedastisitas yaitu untuk mengetahui apakah model regresi yang dihasilkan efisien secara kuantitatif dalam suatu regresi yang dilakukan dengan metode Spearman Rank Correlation. Diperoleh hasil thitung 79,053 sedangkan nilai ttabel pada taraf signifikansi $5 \%$ adalah sebesar 1,983. dengan membandingkan thitung dengan ttabel untuk thitung $>$ ttabel artinya tidak terjadi heteroskedastisitas dalam model regresi. Cara yang lebih mudah yaitu apabila gambar yang dihasilkan tidak membentuk suatu pola tertentu berarti tidak terjadi heteroskedastisitas. Berdasarkan perhitungan diperoleh gambar yang menyebar tidak membentuk suatu pola. Hal ini berarti bahwa model regresi yang dihasilkan tidak terjadi heteroskedastisitas.

3. Uji Autokorelasi

Uji Autokorelasi digunakan untuk mengetahui apakah model regresi yang dihasilkan, varians sampelnya dapat menggambarkan varians populasi sehingga dapat digunakan untuk menaksir nilai variabel dependen pada nilai variabel independen. Berdasarkan hasil perhitungan komputer program SPSS pada Lampiran nilai uji DW dengan tingkat signifikansi $5 \%(0,05)$ diperoleh nilai $\mathrm{dl}=1,634 \mathrm{dan} \mathrm{du}$ $=1,715$. Terbukti bahwa nilai uji Durbin Watson $=1,948$ berada di daerah tidak ada autokorelasi yaitu terletak di antara du $(1,715)$ dan 4-du $(2,285)$ sehingga dapat disimpulkan bahwa pada persamaan regresi dalam penelitian ini tidak terjadi autokorelasi.

\section{Pembahasan}

Berdasarkan hasil penelitian dengan menggunakan uji pengaruh produk (X1), pelayanan (X2), dan lokasi (X3) terhadap keputusan konsumen (Y) secara simultan menunjukkan bahwa ketiga variabel tersebut berpengaruh secara signifikan terhadap keputusan pembelian konsumen pada Toko Ramona Palembang. Bentuk persamaan yang menggambarkan pengaruh variabel bebas terhadap variabel terikat dalam penelitian ini adalah $\mathrm{Y}=4,66+0,204 \mathrm{X} 1+0,4655 \mathrm{X} 2+0,352 \mathrm{X} 3$.

Berdasarkan persamaan regresi berganda yang diperoleh di mana koefisien regresi b1, b2, b3, bertanda positif maka menunjukkan bahwa bentuk pengaruhnya adalah positif, yang artinya jika variabel produk, pelayanan, dan lokasi ditingkatkan secara bersamasama sebesar satu unit, maka keputusan pembelian akan meningkat sebesar 0,204 + $0,4655+0,352$ pada konstanta 4,66 dan sebaliknya jika variabel produk, pelayanan, dan lokasi menurun secara bersama-sama sebesar satu unit, maka keputusan pembelian akan menurun sebesar 0,204 +0,4655+0,352 pada konstanta 4,66.

\section{Variabel Produk (X1)}

Berdasarkan hasil analisis regresi diperoleh koefisien regresi untuk variabel X1 yaitu b1 sebesar 0,204. Dari keberartian koefisien regresi dengan uji t, diperoleh thitung $=2,911$ 
Consumer

Purchasing

Decision and Retail
$>$ ttabel $=1,983$. Dengan demikian dapat dijelaskan bahwa variabel produk (X1) memberikan pengaruh yang positif dan signifikan terhadap keputusan pembelian (Y). jika dilihat dari determinasi parsialnya, variabel produk (X1) memberikan sumbangan terhadap keputusan pembelian sebesar 7,73\%.

Dengan demikian koefisien regresi sebesar 0,204 dan koefisien determinasi parsial sebesar 7,73\% menunjukkan bahwa untuk variabel produk (X1) jika terjadi perubahan sebesar 1 satuan, maka akan menyebabkan perubahan pada keputusan pembelian (Y) sebesar 0,204 satuan atau 7,73\% dengan asumsi variabel pelayanan (X2) dan lokasi (X3) tetap. Variabel produk memiliki pengaruh paling kecil dibandingkan dengan variabel pelayanan dan lokasi. Hal ini menunjukkan bahwa produk yang ditawarkan oleh Toko Ramona Palembang dengan pasar swalayan lain cenderung homogen sehingga produk yang dibutuhkan konsumen tidak hanya ditawarkan di Toko Ramona Palembang melainkan di pasar swalayan lain. Dengan demikian produk tidak memberikan pengaruh yang besar terhadap keputusan pembelian konsumen.

Sedangkan berdasarkan hasil penelitian analisis deskriptif persentase menunjukkan bahwa produk yang ditawarkan di Toko Ramona Palembang termasuk dalam kategori tinggi yaitu $72,1 \%$. Tingginya variabel produk ini didukung oleh kualitas produk yang sudah baik. Kualitas produk merupakan hal yang perlu mendapat perhatian utama dari perusahaan mengingat kualitas produk berkaitan erat dengan masalah keputusan pembelian. Selain itu, produk yang disediakan sudah lengkap sehingga konsumen dapat memilih produk sesuai dengan keinginannya dan dapat menghemat waktu dalam berbelanja. Nilai koefisien regresi variabel produk (X1) bertanda positif ini memberikan indikasi bahwa variabel produk memberikan pengaruh positif terhadap keputusan membeli produk di Toko Ramona Palembang.

\section{Variabel Pelayanan (X2)}

Berdasarkan hasil analisis regresi diperoleh koefisien regresi untuk variabel X2 yaitu b2 sebesar 0,4655. Dari keberartian koefisien regresi dengan uji $t$, diperoleh thitung $=$ $6,231>$ ttabel $=1,983$. dengan demikian dapat dijelaskan bahwa variabel pelayanan (X2) memberikan pengaruh yang positif dan signifikan terhadap keputusan pembelian (Y). jika dilihat dari determinasi parsialnya, variabel pelayanan (X2) memberikan sumbangan terhadap keputusan pembelian sebesar 27,77 \%. Dengan demikian koefisien regresi sebesar 0,4655 dan koefisien determinasi parsial sebesar 27,77 \% menunjukkan bahwa untuk variabel pelayanan (X2) jika terjadi perubahan sebesar 1 satuan, maka akan menyebabkan perubahan pada keputusan pembelian (Y) sebesar 0,4655 satuan atau 27,77 $\%$ dengan asumsi variabel produk (X1) dan lokasi (X3) tetap.

Variabel pelayanan memiliki pengaruh paling besar terhadap keputusan konsumen dalam pembelian dibandingkan variabel produk dan lokasi. Hal ini menunjukkan bahwa pelayanan merupakan faktor terpenting yang harus diperhatikan oleh pasar swalayan. Konsumen yang ingin membeli suatu produk, pelayanan yang diberikan pada saat memilih sampai terjadinya transaksi pembelian sangat berpengaruh terhadap jadi tidaknya konsumen dalam membeli. Dengan demikian dalam suatu perusahaan dalam hal ini pasar swalayan, agar loyalitas konsumen semakin melekat erat dan konsumen tidak berpaling ke swalayan lain, maka swalayan perlu menguasai lima unsur yaitu cepat, tepat, aman, ramah, dan nyaman. Sedangkan berdasarkan hasil analisis deskriptif persentase menunjukkan bahwa pelayanan yang diberikan oleh Toko Ramona Palembang termasuk kategori rendah. Pelayanan yang kurang baik akan mengakibatkan konsumen yang membeli merasa tidak dihargai dan tidak puas sehingga konsumen tidak melakukan pembelian ulang dan pindah ke swalayan lain. Hal ini akan berakibat pada menurunnya jumlah pengunjung dan pada akhirnya nanti keputusan pembelian akan mengalami penurunan. Nilai koefisien regresi variabel pelayanan (X2) bertanda positif ini memberikan indikasi bahwa variabel pelayanan memberikan pengaruh positif terhadap keputusan membeli produk di Toko Ramona Palembang.

\section{Variabel Lokasi (X3)}

Berdasarkan hasil analisis regresi diperoleh koefisien regresi untuk variabel X3 yaitu b3 sebesar 0,352. Dari keberartian koefisien regresi dengan uji t, diperoleh thitung $=5,864$ 

memberikan pengaruh yang positif dan signifikan terhadap keputusan pembelian (Y). jika dilihat dari determinasi parsialnya, variabel lokasi (X3) memberikan sumbangan terhadap keputusan pembelian sebesar 25,40 \%. Dengan demikian koefisien regresi sebesar 0,352 dan koefisien determinasi parsial sebesar 25,40 \% menunjukkan bahwa untuk variabel lokasi (X3) jika terjadi perubahan sebesar 1 satuan, maka akan menyebabkan perubahan pada keputusan pembelian (Y) sebesar 0,352 satuan atau 25,40\% dengan asumsi variabel produk (X1) dan pelayanan (X2) tetap.

Pemilihan lokasi merupakan salah satu pertimbangan konsumen dalam melakukan keputusan pembelian. Lokasi yang benar-benar strategis sangatlah diharapkan konsumen seperti mudah dijangkau, tersedianya sarana transportasi yang cukup mudah, letaknya strategis sehingga lokasi ini akan mendukung yang lain. Berdasarkan hasil analisis deskriptif persentase menunjukkan bahwa lokasi swalayan termasuk kategori sedang yaitu 58,9\%. Hal ini menunjukkan bahwa lokasi yang ada masih perlu ditingkatkan. Untuk itu perlu disediakan fasilitas-fasilitas yang mendukung kelancaran konsumen dalam berbelanja, seperti wartel, ATM, dan sebagainya.

Nilai koefisien regresi variabel lokasi (X3) bertanda positif ini memberikan indikasi bahwa variabel lokasi memberikan pengaruh positif terhadap keputusan membeli produk di Toko Ramona Palembang.

\section{Pengaruh Produk, Pelayanan, dan Lokasi terhadap Keputusan pembelian}

Berdasarkan uraian di atas diketahui bahwa ada pengaruh yang signifikan antara produk, pelayanan, dan lokasi terhadap keputusan pembelian produk di Toko Ramona Palembang. Besarnya pengaruh dari ketiga variabel bebas X1, X2, dan X3 terhadap keputusan pembelian (Y) adalah 0,701 atau $70,1 \%$. Hal ini menunjukkan bahwa produk, pelayanan, dan lokasi memberikan andil yang cukup besar terhadap keputusan konsumen dalam membeli produk di Toko Ramona Palembang.

Sedangkan sisanya 29,9\% dipengaruhi oleh faktor lain di luar model yang tidak dikaji dalam penelitian ini. Dari ketiga faktor yang mempengaruhi keputusan pembelian di Toko Ramona Palembang, ternyata pelayanan memberikan pengaruh yang paling besar yaitu sebesar 27,77 \%. Hal ini disebabkan karena sebagian besar konsumen menyatakan bahwa pelayanan yang diberikan pasar swalayan perlu diperhatikan. Pada umumnya para pramuniaga kurang memperhatikan masalah pelayanan bagi konsumen yang mengunjungi pasar swalayan. Terbukti dari cara mereka melayani konsumen. Dengan demikian konsumen akan merasa kurang puas sehingga akan menimbulkan pengaruh yang sangat besar terhadap keputusan pembelian konsumen. Variabel produk memberikan pengaruh sebesar 7,73\%.

Hal ini disebabkan karena produk merupakan prioritas yang harus diperhatikan agar kepuasan konsumen dapat terbentuk sehingga akan berpengaruh pada pembeliannya. Ini bisa dilihat bahwa Toko Ramona Palembang sangat memperhatikan kualitas dan kelengkapan sehingga banyak konsumen yang merasa puas. Hal inilah yang menyebabkan variabel produk sedikit pengaruhnya terhadap keputusan pembelian konsumen. Buktinya 47,6 \% responden mengatakan kualitas produk baik dan 49,5\% menyatakan produk yang ditawarkan oleh Toko Ramona Palembang lengkap.

Variabel lokasi memberikan pengaruh sebesar 25,40 \%. Hal ini disebabkan karena lokasinya cukup strategis sehingga konsumen dapat dengan mudah untuk menjangkaunya. Variabel produk, pelayanan, dan lokasi masing-masing memberikan pengaruh produk sebesar 7,73\%, pelayanan $27,77 \%$, dan lokasi $25,40 \%$ sedangkan sisanya dipengaruhi oleh variabel lain yang tidak diteliti dalam penelitian ini.

Kemungkinan variabel lain yang mempengaruhi keputusan pembelian adalah promosi, manajemen, dan sebagainya. Jadi, dengan demikian variabel produk memberikan pengaruh paling kecil terhadap keputusan pembelian konsumen karena produk yang ditawarkan oleh Toko Ramona Palembang dengan pasar swalayan lain cenderung homogen. Di sisi lain, variabel pelayanan memberikan pengaruh yang cukup besar terhadap keputusan pembelian konsumen karena pelayanan yang diberikan pasar swalayan bersifat dinamis dan relatif sehingga perlu diperhatikan. 
Consumer PENUTUP

Purchasing Berdasarkan hasil penelitian dan pembahasan dapat disimpulkan sebagai berikut:

Decision and Retail 1. Ada pengaruh positif antara variabel produk, pelayanan, dan lokasi terhadap keputusan pembelian konsumen pada Toko Ramona Palembang. Hal ini dapat dilihat dari hasil perhitungan di peroleh Fhitung 79,053 pada taraf signifikansi $5 \%$ (Ftab = 3,0864). Dengan demikian Fhit $>$ Ftab sehingga dapat disimpulkan bahwa Hipotesis Kerja (Ha) diterima. Sedangkan sumbangan yang diberikan variabel yang diteliti sebesar 70,1 \% dan sisanya $29,9 \%$ dipengaruhi oleh variabel lain selain produk, pelayanan, dan lokasi.

2. Berdasarkan hasil analisis parsial dapat disimpulkan bahwa variabel produk sebesar $7,73 \%$, variabel pelayanan sebesar $27,77 \%$, dan variabel lokasi sebesar 25,40 \%. Jadi dapat disimpulkan bahwa variabel pelayanan mempunyai sumbangan parsial terbesar dibandingkan dengan variabel yang lain.

\section{DAFTAR PUSTAKA}

[1] Algifari. 2010. Analisis Regresi: Teori Kasus dan solusi. Yogyakarta: BPFE.

[2] Arikunto, Suharsimi. 2012. Prosedur Penelitian suatu Pendekatan Praktek. Jakarta: Rineka Cipta.

[3] Assauri, Sofjan. 2014. Manajemen Pemasaran. Jakarta: Rajawali Press. Cooper dan Emory. 2009. Metode Penelitian Bisnis. Jakarta: Erlanggga.

[4] Hadi, Sutrisno. 2004. Statistik. Yogyakarta: Andi Offset.

[5] Lupiyoadi, Rambat. 2011. Manajemen Pemasaran Jasa Teori dan Praktek. Jakarta: Rineka Cipta.

[6] Kotler, Philip. 2010. Manajemen Pemasaran di Indonesia: Analisis, Perencanaan, implementasi, dan pengendalian. Jakarta: Salemba Empat.

[7] Sitepu, Nirwana. 2004. Analisis Jalur. Bandung: Unit Pelayanan Statistik Univrsitas Padjajaran.

[8] Sriyadi.2001. Bisnis Pengantar Ilmu Perusahaan Modern. Semarang: IKIP Press.

[9] Sugiarto, Endar. 2012. Psikologi Pelayanan dalam Industri Jasa. Jakarta: Gramedia Sudjana. 1996. Metode Statistika. Bandung:

[10] Tarsito. Swasta, Basu. 2006. Asas-asas marketing. Yogyakarta. : Liberty.

[11] Swasta, Basu dan T Hani Handoko. 2010. Manajemen Pemasaran: Analisa dan Perilaku Konsumen. Yogyakarta: BPFE.

[12] Swasta, Basu dan Irawan. 2013. Manajemen Pemasaran Modern. Yogyakarta: Liberty.

[13] Tjiptono, Fandy. 2010. Strategi Pemasaran. Yogyakarta: Andi Offset.

[14] Tjiptono, Fandy. 2010. Manajemen Jasa. Yogyakarta: Andi Offset.

[15] Usman dan Setiady. 2010. Metodologi Penelitian Sosial. Jakarta: Bumi Aksara.

[16] Wijaya, Juhana. 2009. Pelayanan Prima. Bandung: Armico

[17] Purba, J.H.V., 2017. The analysis of European Union's vegetable oil consumption:" will the European Parliament Resolution Halt the Consumption of Crude Palm Oil in the European Union in the future?". International Journal of Applied Business and Economic Research, 15, p.19.

[18] Putra, A.G. and Zuhdi, S., 2018. The Influence of Repositioning Strategies on Purchase Intention Through Brand Personality and Brand Association. In THE INTERNATIONAL CONFERENCE ON ACCOUNTING AND MANAGEMENT SCIENCE (p. 158).

[19] Zuhdi, S., Daud, A., Hanif, R., Nguyen, P.T. and Shankar, K., 2019. Role of Social Media Marketing in the Successful Implementation of Business Management. International Journal of Recent Technology and Engineering, 8.

[20] Zuhdi, S., Rainanto, B.H. and Apriyani, D., 2020, May. Analysis of Co-Branding Strategy to Improve Company's Competitive Power (Case Study on Walls Selection Oreo). In 2nd International Seminar on Business, Economics, Social Science and Technology (ISBEST 2019) (pp. 146-149). Atlantis Press. 